Acta vet. scand. $1970,11,545-564$.

From the Department of Medicine, Veterinary College of Norway, Oslo.

\title{
WINTER RESISTANT OOCYSTS \\ IN THE PASTURE AS A SOURCE OF COCCIDIAL INFECTION IN LAMBS
}

By

Oddvar Helle

It has been observed that coccidiosis may be an important disease of lambs in Norway about 3 weeks after they have been turned out on pasture in the spring (Helle 1964). There has been strong evidence that the main source of infection is oocysts that have survived the winter in the pasture, as the disease has been most frequent on pastures which have been grazed by sheep for several consecutive years, whereas lambs on pastures never grazed by sheep before have shown a low rate of infection (Helle 1967). These subjects have been further studied on a research farm near Oslo. One group of sheep has been kept on the same lowland cultivated pasture from 1960 to 1968 without treatment against nematodes or coccidia. On an adjacent pasture sheep have been kept from 1961 onward, and ewes and lambs have been treated fortnightly against nematodes during the entire grazing periods. From 1964 onward $75 \mathrm{mg} / \mathrm{kg}$ thiabendazole has been given, and ewes as well as lambs have been almost completely free of nematodes. On both these pastures symptoms of coccidiosis have appeared from about 12 days after the beginning of grazing. Some lambs have died of a profuse diarrhoea and emaciation. On pastures not grazed by sheep the previous years there has been no clinical appearance of coccidiosis.

The time of onset of the clinical symptoms in the lambs indicated that they have been infected during their first days on pasture, as experimentally induced infections have shown that the first symptoms of coccidiosis are observed 10-12 days after infection (Christensen 1941, Lotze 1953, Shumard 1959). In this paper some observations concerning the mechanism of coccidial 
infection will be presented. All the data presented here refer to thiabendazole-treated lambs. Pastures grazed by sheep the previous years are called permanent and those not grazed by sheep earlier are called new pastures.

The experiments of 1967 included 1 group of lambs on permanent pasture, a second group on permanent pasture for 2 days and thereafter transferred to a new pasture, a third group on permanent pasture for 2 days and then housed, a fourth group on a new pasture, and a fifth continually housed on slatted floor. In 19681 group of lambs grazed the same permanent pasture as in 1967, and another group was on a new pasture.

It has been observed that lambs which have been housed from birth, often eat soil when transferred to pasture. During 1967 and 19683 experiments involving the tube feeding of soil to lambs were carried out. Soil from permanent pasture as well as from ungrazed area was used.

\section{MATERIALS AND METHODS}

The farm W $\phi y e n$ lies about $50 \mathrm{~km}$ south-west of Oslo about $40 \mathrm{~m}$ above sea level.

The climate is typical of eastern Norway with permanent snow cover and sub-zero temperatures from December to March or April. Meteorological data have been taken from the For$\mathrm{n}$ e b u station, which is a few $\mathrm{km}$ from the farm.

The pastures. The permanent pasture was on a south-western slope on sandy soil with some proportion of clay. The new pastures were on a plain with less clay. Most of the pastures had a good grass cover, but there were also areas with trees, bushes and grass of inferior quality. The stocking rate was high enough to prevent overgrowth of grass.

Housing. The 6 lambs of Experiment no. 4 were housed in concrete pens with their mothers. The pens had clean sawdust litter which was cleaned out daily. All other sheep were housed in pens with wooden slatted floor and with well-constructed troughs. The lambs had a separate creep where concentrates were given. In early spring the temperature was about $10^{\circ} \mathrm{C}$, but later it increased to about $20^{\circ} \mathrm{C}$. The lambs of different grazing experiments were kept together in the same pens before they went out on pasture. Each group of lambs tube fed with soil was separated from the other groups after the procedure. 
Experimental animals. The Experiments nos. 1 and 3 involved twin ewes with their lambs. Pairs of comparable ewes were made, and the grouping was done at random. The other experiments included twins as well as single lambs. Within each experiment homogenous blocks were made which were further grouped at random. Tables 1 and 2 give a survey of the experimental groups.

Table 1. Design of experiments with lambs exposed to natural infection and their controls.

\begin{tabular}{ccccclc}
\hline Year & Exp. & Gr. & $\begin{array}{c}\text { No. of } \\
\text { lambs }\end{array}$ & $\begin{array}{l}\text { Age of lambs } \\
\text { in days at } \\
\text { beg. of gra- } \\
\text { zing, range }\end{array}$ & Environment & $\begin{array}{c}\text { Pasture } \\
\text { no. }\end{array}$ \\
\hline 1967 & $1-1$ & 10 & $19-39$ & $\begin{array}{l}\text { permanent pasture } \\
\text { new pasture }\end{array}$ & 4 \\
& 2 & 12 & $14-39$ & 10 \\
\hline & $2-1$ & 8 & $20-37$ & $\begin{array}{l}\text { permanent pasture } \\
\text { 2 days + new pasture }\end{array}$ & $4+11$ \\
& 2 & 8 & $20-38$ & $\begin{array}{l}\text { permanent pasture } \\
\text { 2 days + housed } \\
\text { housed on slatted floor; }\end{array}$ & 4 \\
& & & 11 & $31 *-37$ & $\begin{array}{l}\text { from 10 June, see } \\
\text { Table 2. }\end{array}$ & 4 \\
\hline 1968 & $3-1$ & 10 & $9-28$ & $\begin{array}{l}\text { permanent pasture } \\
\text { new pasture }\end{array}$ & 12 \\
\hline
\end{tabular}

* in addition 1 lamb born 2 days after other sheep went on pasture.

The housed control group no. 3 of Experiment no. 2 in Table 1 was subdivided for tube-feeding with soil on the 10th of June in 1967. From that time this group was called Experiment no. 5 with 5 sub-groups as specified in Table 2.

Soil for the experimental infecting of lambs was both years collected on the permanent pasture no. 4 on the day when the sheep were turned out, but before any of them had entered the area. The soil samples were taken from 3 places where the sheep usually rested in the shadow. Remaining visible faeces were removed, and $200 \mathrm{~g}$ of the upper surface of the soil was collected with a spoon. In 1967 soil from an ungrazed area was collected outside Pasture 4 from an area of higher elevation than the pasture, and where no animal had entrance. In 1968 soil samples 
Table 2. Design of experiments which included lambs treated with soil.

\begin{tabular}{|c|c|c|c|c|c|c|c|c|}
\hline \multirow[t]{2}{*}{ Year } & \multirow[t]{2}{*}{ Exp. } & \multirow[t]{2}{*}{ Gr. } & \multicolumn{2}{|c|}{ Soll dosed } & \multirow{2}{*}{$\begin{array}{l}\text { No. of } \\
\text { lambs }\end{array}$} & \multirow{2}{*}{\multicolumn{2}{|c|}{$\begin{array}{c}\text { Age of lambs } \\
\text { in days at } \\
\text { treatment, } \\
\text { range }\end{array}$}} & \multirow[t]{2}{*}{ Environment } \\
\hline & & & 8 & source & & & & \\
\hline \multirow[t]{9}{*}{1967} & 4 & 1 & 10 & Past. 4 & 1 & & 33 & concrete pen \\
\hline & & 2 & 25 & Past. 4 & 1 & & 33 & concrete pen \\
\hline & & 3 & 50 & Past. 4 & 1 & & 57 & concrete pen \\
\hline & & 4 & $\mathbf{0}$ & & 3 & 57 & -61 & concrete pen \\
\hline & $5^{\star}$ & 1 & 25 & Past. 4 & 1 & & 23 & slatted floor \\
\hline & & 2 & 50 & Past. 4 & 2 & 58 & -62 & slatted floor \\
\hline & & 3 & 25 & ungrazed & 1 & & 56 & slatted floor \\
\hline & & 4 & 50 & ungrazed & 2 & 44 & -61 & slatted floor \\
\hline & & 5 & 0 & & 5 & 46 & -62 & slatted floor \\
\hline \multirow[t]{3}{*}{1968} & 6 & 1 & 50 & Past. 4 & 7 & 12 & -31 & slatted floor \\
\hline & & 2 & 50 & orchard & 7 & 12 & -29 & slatted floor \\
\hline & & 3 & 0 & & 7 & 12 & -28 & slatted floor \\
\hline
\end{tabular}

* until 10 June these lambs were control group (no. 3) of Exp. no. 2. From 10 June the group was subdivided into 5 groups and called Exp. no. 5.

were taken from an ungrazed area in a private orchard with soil similar to Pasture 4.

Examination of soil. The samples of 1967 were mixed and 10 samples, each of $3 \mathrm{~g}$, were weighed out and examined by the McMaster technique with saturated salt flotation, as for faecal samples. In addition, 1 sample of $10 \mathrm{~g}$ and 1 of $50 \mathrm{~g}$ were mixed with water and transferred to centrifuge glasses and centrifuged. The supernatant was poured off, and the glasses were refilled with $35 \%$ sugar solution and centrifuged with cover glasses on top. The material adhering to the cover glass was examined by $60 \times$ and $270 \times$ magnification.

Oral administration of soil. 'The soil was suspended in $200 \mathrm{ml}$ water, sieved through a coarse coffee-strainer, and the suspension given with a stomach tube.

- Faecal samples were taken regularly from the rectum of all lambs of each group. In small lambs conical glass tubes were used. During some periods samples were collected 3 times a week. The oocysts were counted by a modified McMaster technique (Helle 1964) and expressed as OPG (oocysts per $\mathrm{g}$ of faeces). 
Statistical examinations of the oocyst counts were done by t-tests on log.-transformed oocyst counts between 2 corresponding groups on each sampling day. The transformation has been done by the formula $\log$. $(n+1)$ where $n$ is the number of oocysts found in 4 McMaster chambers. OPG is $n$ multiplied by 50 . The $5 \%$ level has been used as the limit of significant differences. This has been indicated by 1 asterisk below the abscissa of the figures. Only 1 asterisk has been used even at higher degrees of significance between the groups.

The occurrence of diarrhoea in lambs on a high and low level of exposure to infection within each experiment has been evaluated by Fisher's test (Siegel 1956). In addition the occurrence of diarrhoea in pooled groups on a high level of infection has been compared with diarrhoea in pooled groups on a low level of infection by the chi-square analysis.

Specification of oocysts was done according to Joyner et al. (1966).

\section{RESULTS}

F i g. 1 shows the mean log. $(O P G+1)$ of lambs in Experiment no. 1 which included lambs on permanent and new pasture in 1967. From 16 to 30 days after the beginning of grazing there is a significant difference between the groups.

F i g. 2 shows the mean log. $(O P G+1)$ of lambs in Experiment no. 2 which included permanently housed lambs, lambs which grazed 2 days on permanent pasture (no. 4) and then were housed again, and lambs which were transferred to new pasture after 2 days on permanent pasture. The 2 latter groups of lambs had significantly higher oocyst counts than permanently housed lambs during periods which began 16 and 14 days respectively after the beginning of grazing on permanent pasture.

$\mathrm{F}$ i g. 3 shows the mean $\log$. $(\mathrm{OPG}+1)$ of lambs on permanent and new pasture in Experiment no. 3 in 1968. The difference between the groups was highly significant in a period beginning 17 days after the lambs had been turned out on pasture.

Fig. 4 shows the individual $\log$. $(O P G+1)$ of 3 lambs in Experiment no. 4 which were experimentally infected with soil from Pasture 4 and of 3 control lambs. Sixteen days after the infection occurred there was an increase of oocyst counts in the infected lambs. 


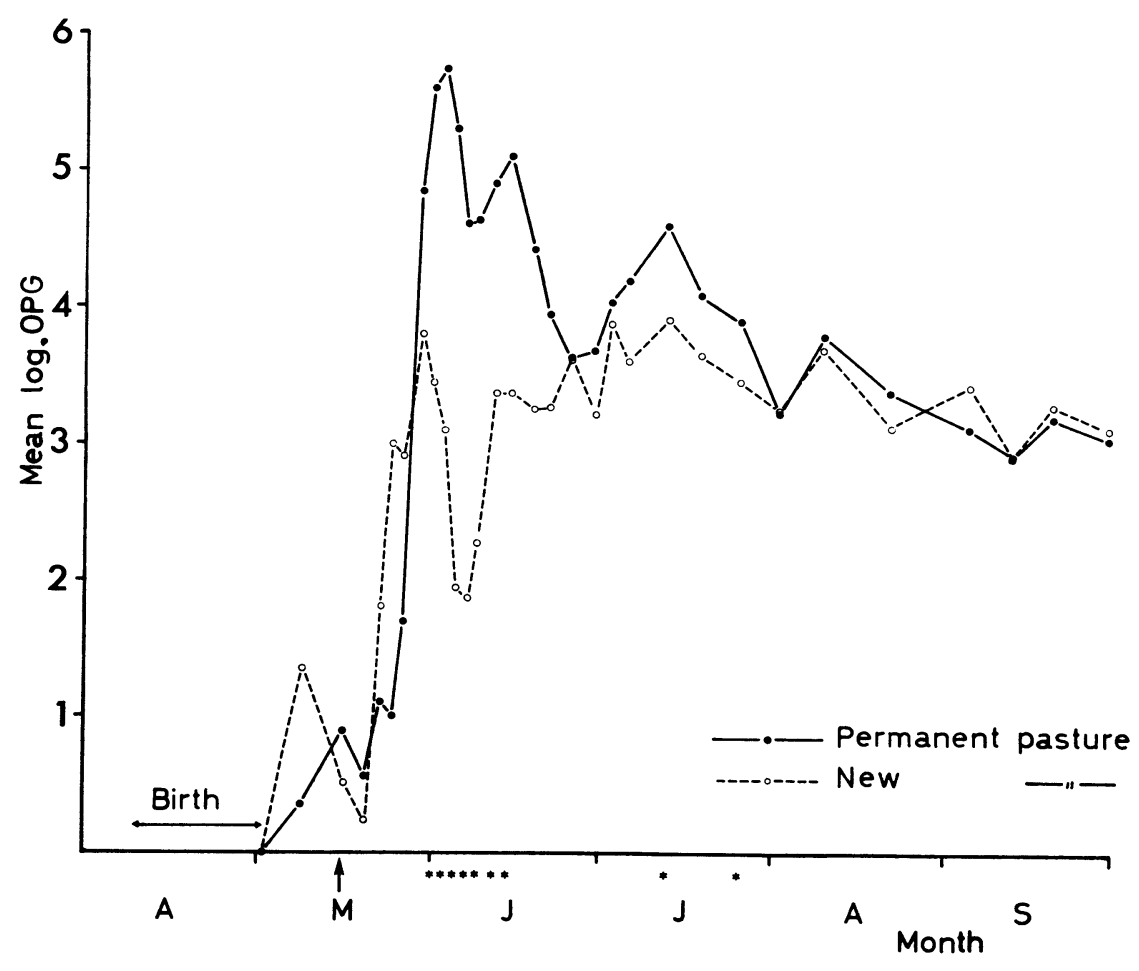

Figure 1. Mean log. $(O P G+1)$ of lambs on permanent and new pastures in 1967 (Experiment no. 1). Arrow below the abscissa indicates the first day on pasture. Each asterisk below the abscissa shows that the difference of mean log. $(O P G+1)$ between the groups was significant on that date.

F i g. 5 shows the mean log. $(O P G+1)$ of lambs in Experiment no. 5 which included lambs tube-fed with soil from Pasture 4 , soil from an orchard and untreated controls. Fifteen days after gavage with infected soil the oocyst counts of the lambs rose significantly above that of the untreated controls.

On comparing lambs tube-fed with infected and clean soil it was found that from 20 days onward after gavage the oocyst count of the former rose above that of the latter. On 7 sampling days the difference was significant, interrupted by 2 short periods without significant differences.

T a b l e 3 shows individual oocyst counts in lambs in Experiment no. 4. The highest individual oocyst counts are given separately for the period prior to experimentally induced infection with soil and during the incubation period of 12 days from infection. The date of individual peak oocyst counts is also given. 


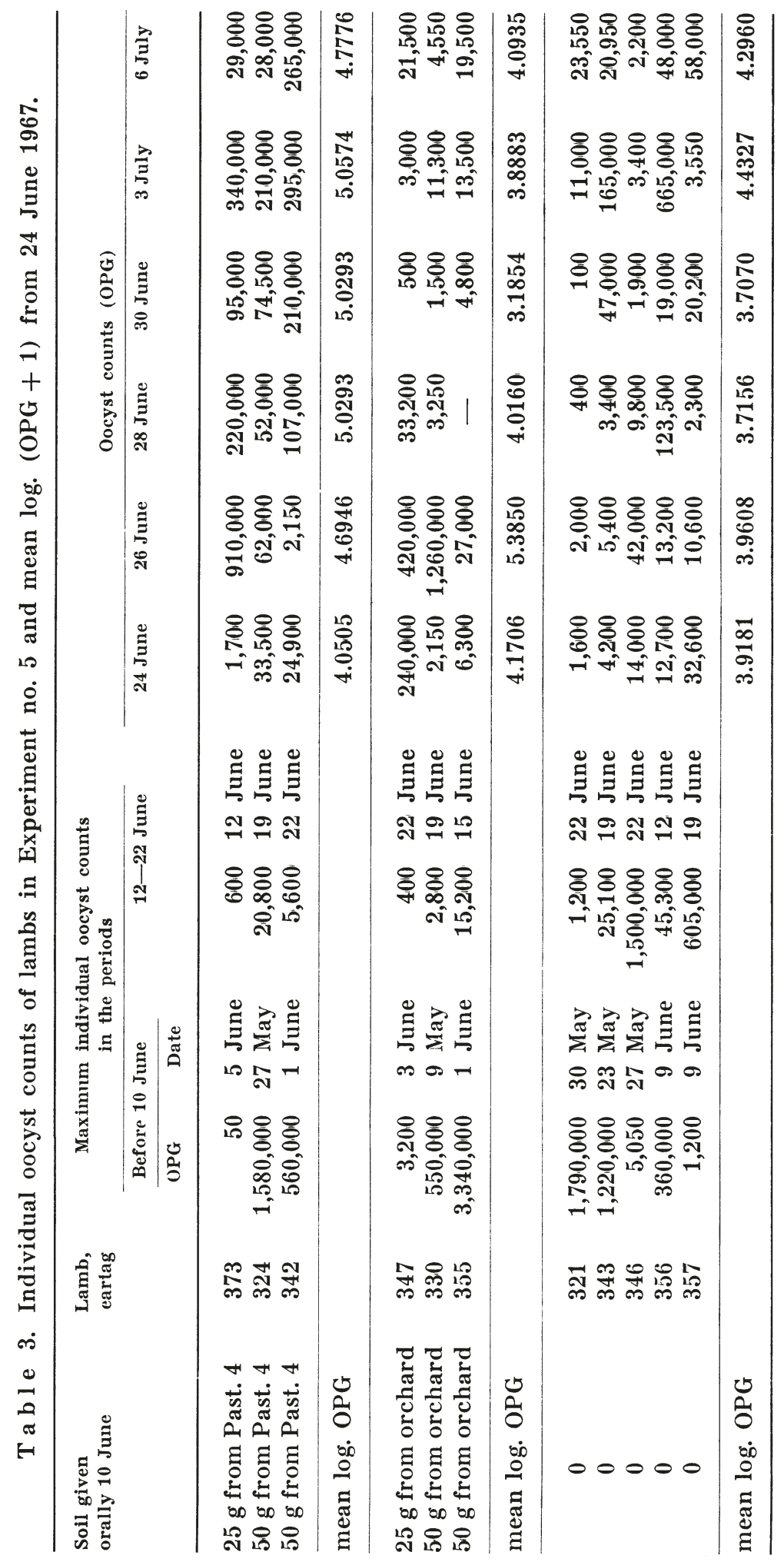




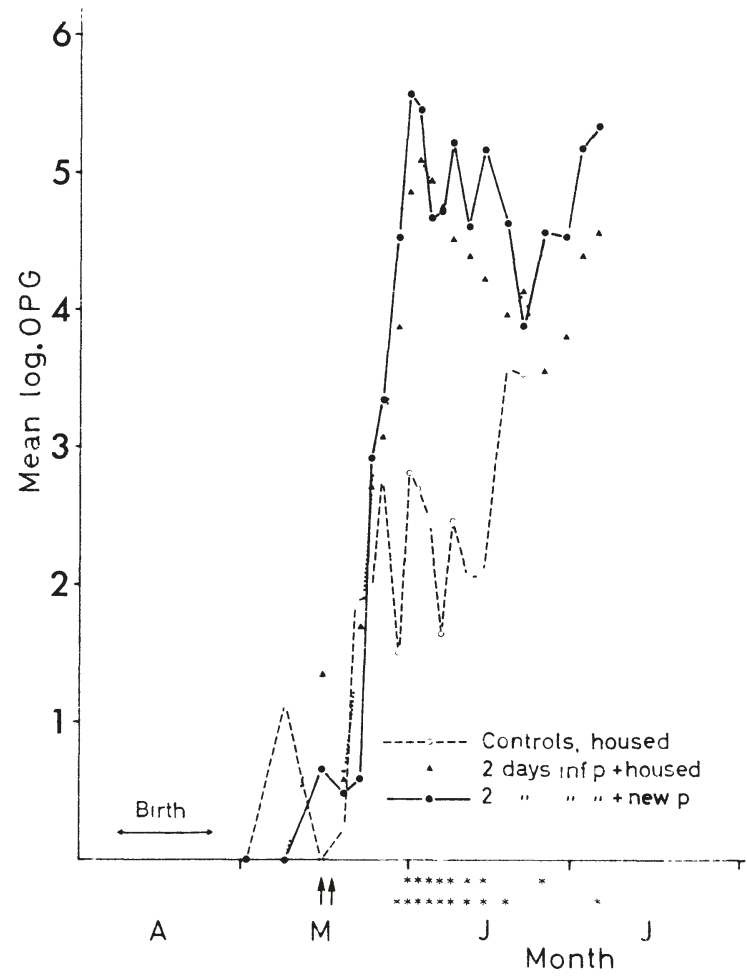

F igu r e 2. Mean log. $(O P G+1)$ of lamb groups which grazed 2 days on permanent (infected) pasture and thereafter were housed or transferred to new pasture, and of housed control lambs (Experiment no. 2). The upper row of asterisks shows the dates when the difference was significant between housed control lambs and lambs which were housed after 2 days on permanent pasture. The lower row of asterisks shows the dates when the difference was significant between housed controls and lambs transferred to new pastures after grazing 2 days on permanent pasture. The 2 arrows below the abscissa indicate the period on permanent pasture.

From the 14th day after experimentally induced infection all individual oocyst counts are shown. The table also shows the mean log. $(O P G+1)$ of each group of the latter period. The oocyst counts of this experiment are very irregular, as some lambs had their peak oocyst counts before they were experimentally infected as well as in the incubation period.

T a ble 4 shows the occurrence of diarrhoea in all groups $11-25$ days after the beginning of grazing or experimentally induced infection with soil. The term "high" is used for the 
$T$ a b l e 4. Number of lambs with diarrhoea between 11 and 25 days after the beginning of grazing or exposure to experimentally produced infection.

\begin{tabular}{|c|c|c|c|c|c|c|}
\hline Exp. & Gr. & $\begin{array}{l}\text { Source of } \\
\text { infection }\end{array}$ & $\begin{array}{l}\text { Supposed } \\
\text { grade of } \\
\text { infection }\end{array}$ & $\begin{array}{c}\text { Diarrhoea } \\
\text { between } 11 \\
\text { and } 25 \text { days } \\
\text { after sup- } \\
\text { posed inf. }\end{array}$ & Total & $\begin{array}{l}\text { Fisher's test } \\
\text { one-sided } \\
\text { high v. low }\end{array}$ \\
\hline \multirow[t]{2}{*}{1} & 1 & perm. past. & high & 6 & 10 & \multirow{2}{*}{$\mathrm{P}<0.05$} \\
\hline & 2 & new past. & low & 2 & 12 & \\
\hline \multirow[t]{3}{*}{2} & 1 & $\begin{array}{l}\text { perm past. } \\
+ \text { new past. }\end{array}$ & high & 3 & 8 & \multirow{3}{*}{$\mathrm{P}>0.05$} \\
\hline & 2 & $\begin{array}{l}\text { perm. past. } \\
+ \text { housed }\end{array}$ & high & 0 & 8 & \\
\hline & 3 & housed & low & 1 & 11 & \\
\hline \multirow[t]{2}{*}{3} & 1 & perm. past. & high & 5 & 10 & \multirow{2}{*}{$\mathrm{P}<0.025$} \\
\hline & 2 & new past. & low & 0 & 10 & \\
\hline \multirow[t]{4}{*}{4} & 1 & $\begin{array}{l}10 \mathrm{~g} \text { inf. } \\
\text { soil, housed }\end{array}$ & high & 1 & 1 & \multirow{4}{*}{$\mathrm{P}<0.05$} \\
\hline & 2 & $\begin{array}{l}25 \mathrm{~g} \text { inf. } \\
\text { soil, housed }\end{array}$ & high & 1 & 1 & \\
\hline & 3 & $\begin{array}{l}50 \mathrm{~g} \text { inf. } \\
\text { soil, housed }\end{array}$ & high & 1 & 1 & \\
\hline & 4 & control, housed & low & 0 & 3 & \\
\hline \multirow[t]{5}{*}{$\overline{5}$} & 1 & $\begin{array}{l}25 \mathrm{~g} \text { inf. } \\
\text { soil, housed }\end{array}$ & high & $\mathbf{0}$ & 1 & \multirow{5}{*}{$P>0.05$} \\
\hline & 2 & $\begin{array}{l}50 \mathrm{~g} \text { inf. } \\
\text { soil, housed }\end{array}$ & high & 1 & 2 & \\
\hline & 3 & $\begin{array}{l}25 \text { g clean } \\
\text { soil, housed }\end{array}$ & low & 0 & 1 & \\
\hline & 4 & $\begin{array}{l}50 \text { g clean } \\
\text { soil, housed }\end{array}$ & low & $\mathbf{0}$ & 2 & \\
\hline & 5 & control, housed & low & 0 & 5 & \\
\hline \multirow[t]{3}{*}{6} & 1 & $\begin{array}{l}50 \mathrm{~g} \text { inf. } \\
\text { soil, housed }\end{array}$ & high & 7 & 7 & \multirow{3}{*}{$\mathrm{P}<0.005$} \\
\hline & 2 & $\begin{array}{l}50 \text { g clean } \\
\text { soil, housed }\end{array}$ & low & 0 & 7 & \\
\hline & 3 & control, housed & low & 0 & 7 & \\
\hline
\end{tabular}




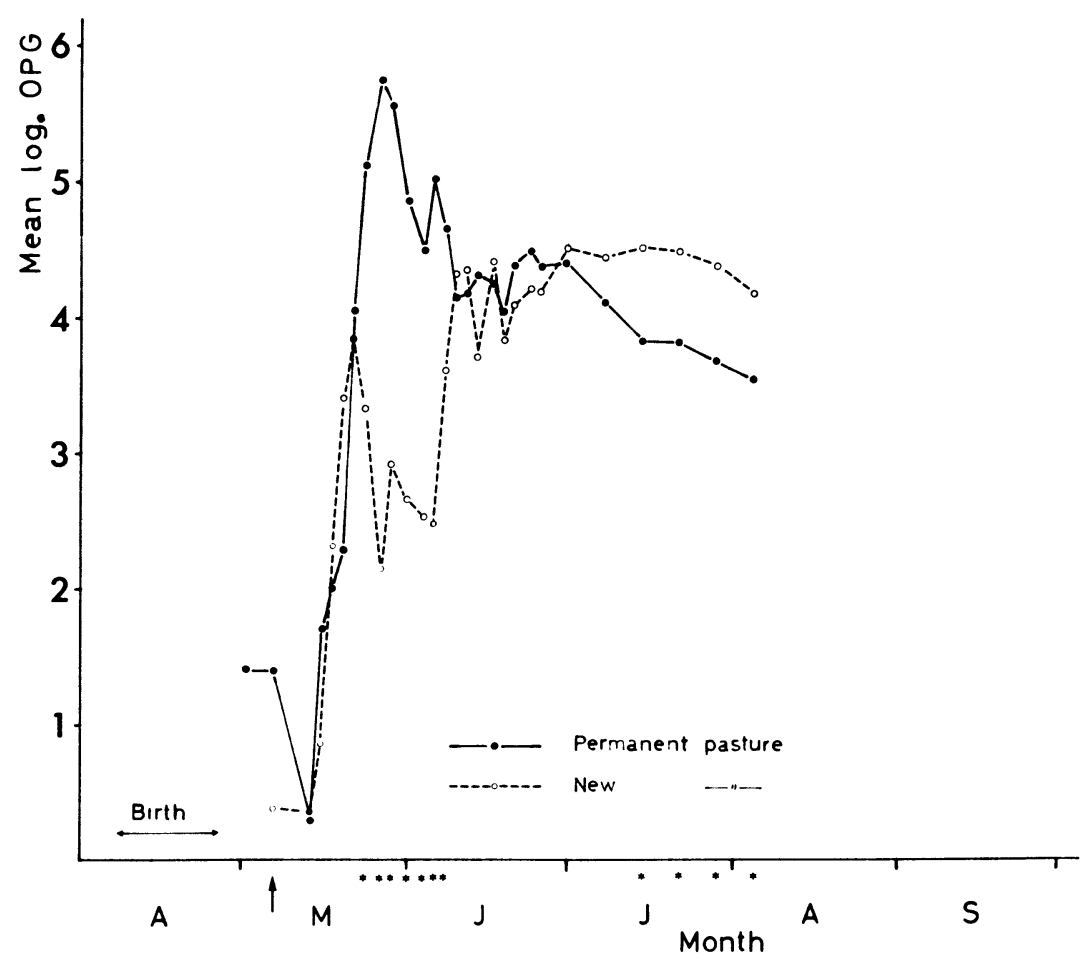

Figure 3. Mean log. $(O P G+1)$ of lambs on permanent and new pastures in 1968 (Experiment no. 3). Symbols as in Fig. 1.

level of infection assumed to be present in the permanent pastures and the soil from these used for the experimentally induced infection, and "low" for the new pastures, soil from the ungrazed areas and the indoor pens. Within each experiment groups subjected to a high level of infection have been pooled and compared with corresponding groups on a low level of infection by Fisher's test. The difference between high and low levels of infection was significant in Experiments no. 1, 3, 4 and 6, but not in 2 and 5.

T a b l e 5 shows the total number of lambs with diarrhoea in the pooled groups on high and low levels of infection respectively. The difference in the frequency of diarrhoea 11-25 days after exposure to infection was highly significant when compared with that of lambs on low levels of infection.

In the period when diarrhoea reached the peak, some lambs had a softening of faeces called "paste". This was more prevalent 


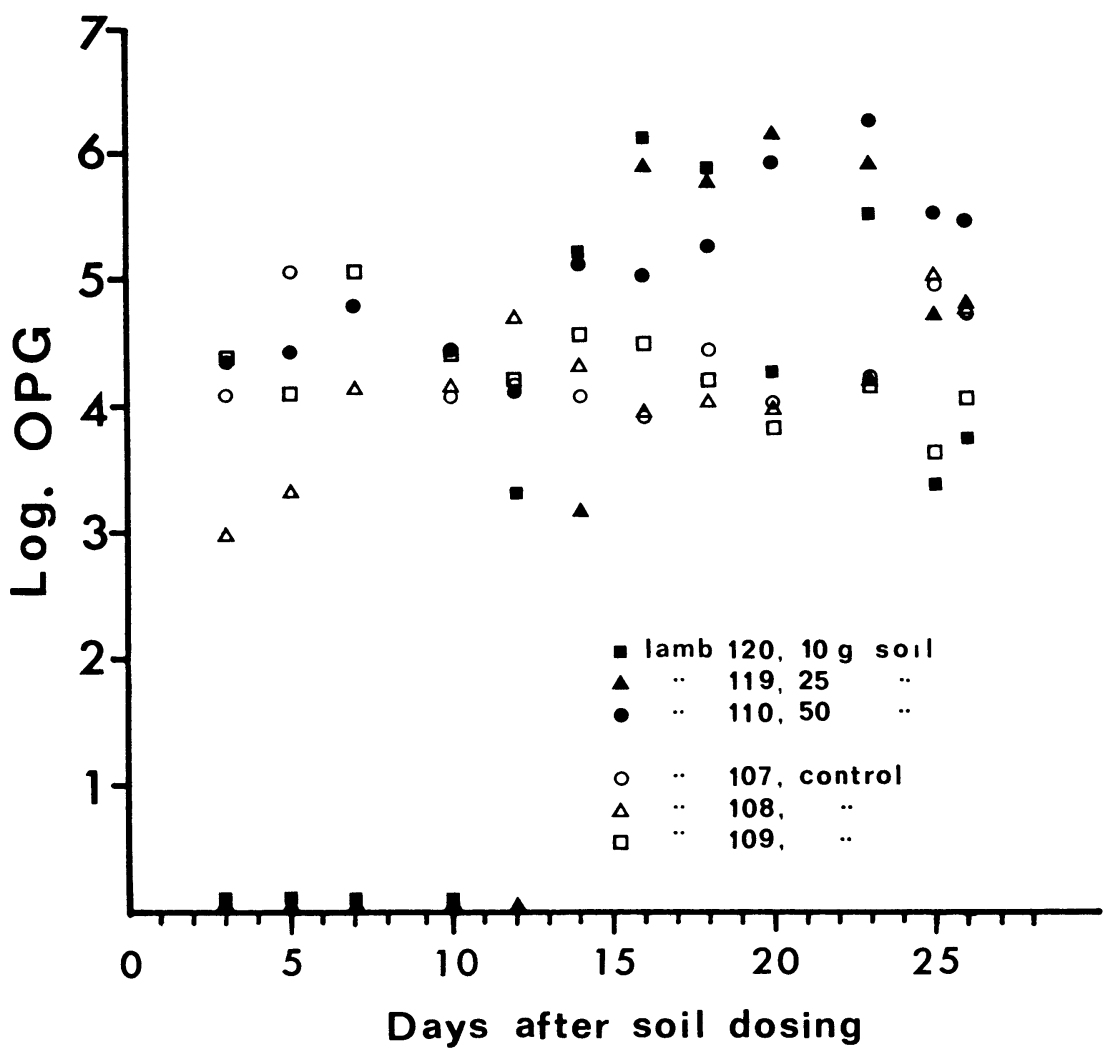

F i g u r e 4. Individual log. $(O P G+1)$ of 6 lambs of Experiment no. 4 in relation to tube-feeding with infected soil to 3 of the lambs.

T a ble 5. Total number of lambs with diarrhoea between 11 and 25 days after exposure to infection in pooled groups on high level of infection (permanent pasture and soil from permanent pasture) and in pooled groups on low level of infection (new pasture, soil from orchard and housed controls).

\begin{tabular}{lccc}
\hline & Diarrhoea & No diarrhoea & Total \\
\hline Exposed to infection & 25 & 24 & 49 \\
Not exposed & 3 & 55 & 58 \\
\hline Total & 28 & 79 & 107 \\
\hline
\end{tabular}

$$
\chi^{2}=26.57^{\star \star} \text { (with Yates correction) }
$$




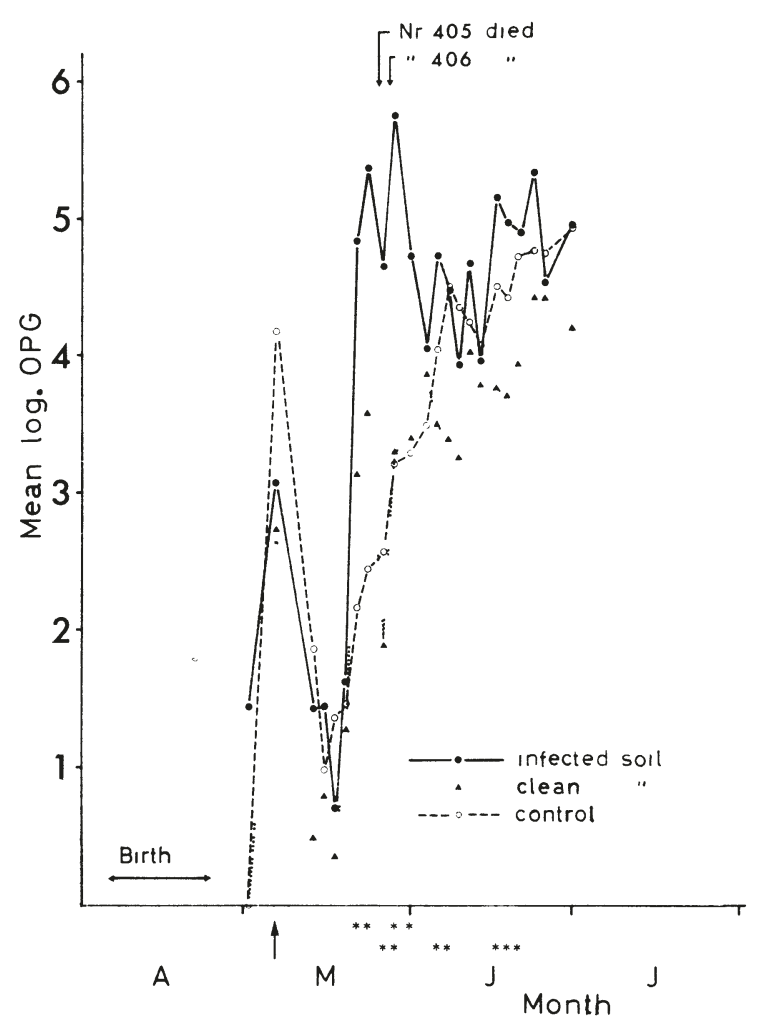

F igure 5. Mean log. $(O P G+1)$ of lambs in Experiment no. 6 which included the tube-feeding with infected soil to 7 lambs and clean soil to 7 lambs. The upper row of asterisks below the abscissa shows the dates when the difference was significant between undosed control lambs and lambs dosed with infected soil. The lower row of asterisks shows the dates when the difference was significant between lambs dosed with clean and infected soil.

in the groups on the high level of infection, but it also occurred at other times in all groups, and this kind of faecal softening is not presented.

F i g. 6 shows the first day of diarrhoea in relation to the first day of exposure to infection in 25 lambs exposed to a high level of infection and in 3 lambs on a low level of infection.

The lamb which developed diarrhoea 7 days after the beginning of grazing on infected pasture was not included in Table 4. This lamb had a new softening of faeces of the "paste" type 16 days after exposure to infection. 


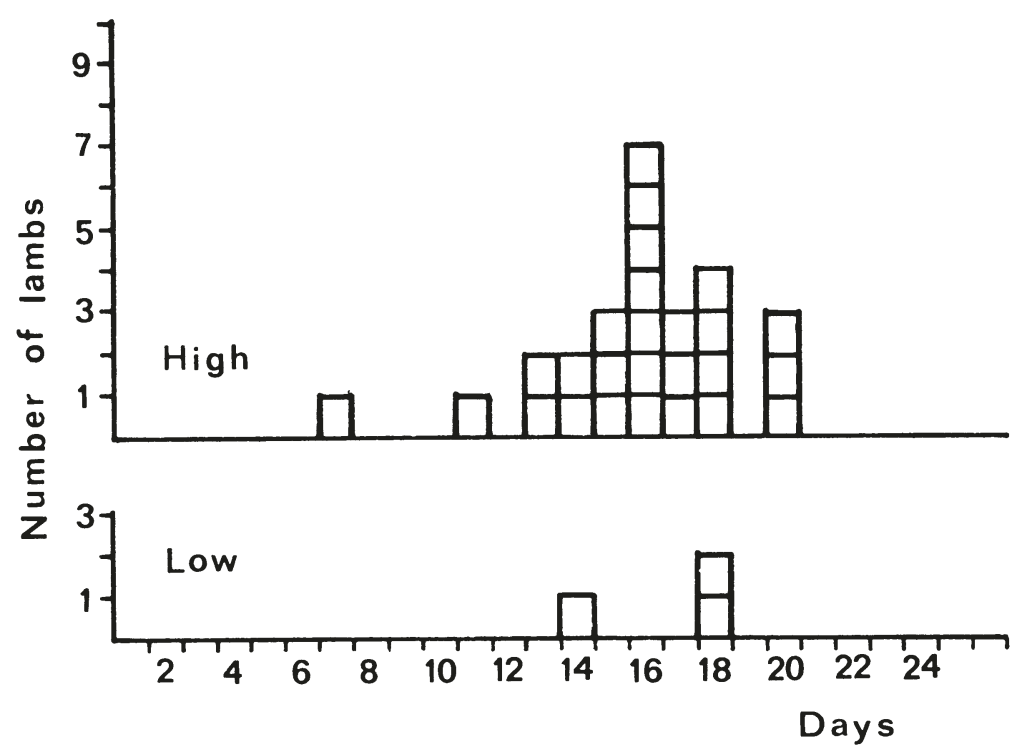

Figure 6. The first day with diarrhoea in relation to the first day of exposure to infection of 26 lambs on high level of infection, and of 3 lambs on low level of infection.

On examination of $103 \mathrm{~g}$ samples of soil by the McMaster technique no oocysts were found. In the samples of 10 and $50 \mathrm{~g}$, where $35 \%$ sugar solution was used for flotation, a moderate number of sporulated oocysts were found. Most of these were E. arloingi.

On routine examination of faeces no specification of the oocysts was done. It was evident that most of the common sheep species of coccidia were present, including Eimeria ahsata, E. arloingi, E. crandallis, E. faurei, E. ninaekohlyakimovae, E. parva, E. pallida and E. intricata. At the time when the oocyst counts reached the peak on permanent pasture, E. arloingi was the most prevalent. It was found, however, that the distinction between this species and E. ahsata and E. crandallis was difficult, but both of the latter were present to some extent.

Clinical condition of lambs. Most of the lambs which had diarrhoea showed anorexia, dullness and lassitude for a short period. Some lambs remained in a poor condition for a longer period. Two of the lambs which were tube-fed with infected soil in 1968 died. Lamb no. 405 died 19 days after feeding. It had haemorrhagic diarrhoea beginning 13 days after gavage with 
soil. Lamb no. 406 died 21 days after being experimentally infected, and it had diarrhoea from 19 days after gavage.

\section{Post-mortem examination}

At the post-mortem examination the intestines of lamb no. 405 were cadaverous and not fitted for histological examinations. The intestines of lamb 406 were fixed in a better condition. An acute enteritis with cellular infiltration of the subepithelial tissue of jejunum and ileum was found, and there were developing stages of coccidia in the epithelial cells.

\section{The climate}

During the winters from 1966 to 1967 and from 1967 to 1968 the mean monthly temperature was below zero in December, January and February, with the lowest values of $-8.5^{\circ} \mathrm{C}$ in January of 1967 and $-7.7^{\circ} \mathrm{C}$ in 1968 . The lowest absolute minimum temperatures were $-24.3^{\circ} \mathrm{C}$ in January of 1967 and $-24.0^{\circ} \mathrm{C}$ in January of 1968 . The fields were covered with snow from the end of November to the late half of March in 1966/67 and from the end of November to the first half of April in 1967/68.

\section{DISCUSSION}

The shortest known period from the time of infection to the appearance of oocysts in the faeces of the lambs is 15 days with Eimeria crandallis (Pout 1965), E. ninaekohlyakimovae (Shumard 1959) and 16-17 days with E. parva (Kotlán et al. 1951). With E. arloingi, which is common in sheep, Lotze (1953) found oocysts in faeces of sheep 20 days after the infection occurred.

In the present experiments all lambs had been kept together in the same pens and thereby been exposed to the same level of coccidial infection during the housing period. The infection caused by coccidia was usually extremely low in young lambs housed on slatted floor in early spring, although individual lambs occasionally had high numbers of oocysts in the faces from 3 weeks of age.

On new pastures, where no residual infection was expected, the oocyst counts remained on a moderate level in the lambs the first weeks on pasture. Since the pastures were contaminated by the lambs and ewes from spring onward it seems reasonable to 
assume that the lambs became infected at an increasing rate with subsequent increase of oocysts in the faeces.

The steep increase in the oocyst counts in lambs on permanent pasture after about 16 days indicated that they must have been exposed to infection during their first days on pasture. The highly significant difference between the oocyst counts in lambs on new and permanent pastures about 3 weeks after the beginning of grazing shows that the initial infection of the 2 types of pasture has been entirely different. The only reasonable explanation of this phenomenon, which has occurred every year from 1965 to 1968 , is that a residuum of oocysts that had survived the winter is responsible for the high rate of infection in lambs on permanent pasture. This confirms the statements given in the preliminary report (Helle 1967).

In 1967 the number of oocysts in the faeces of lambs which grazed 2 days only on permanent pasture and lambs which remained on the permanent pasture was very similar. Whether the lambs were housed again or transferred to a new pasture after the 2 days on permanent pasture had little influence on the further development of oocysts in the faeces.

In housed control lambs the development of oocysts was very similar to that in lambs on new pastures.

These results clearly demonstrate that lambs quickly pick up a large number of oocysts on infected pasture.

In 1967 as well as in 1968 there was a significantly higher frequency of diarrhoea in lambs on permament pasture compared with lambs on new pastures. The time of onset of diarrhoea corresponds to an infection during the first days on pasture. The occurrence of diarrhoea was lower in the lambs which grazed the permanent pasture for two days than in lambs which remained on that pasture. This is reasonable as the latter lambs had more time to pick up a heavier infection.

The figures show that the oocyst counts of lambs housed continuously on slatted floor increased in late spring, and diarrhoea occurred in some lambs at different times. In late spring the temperature inside the house rose to $20^{\circ} \mathrm{C}$ or more, and the humidity increased. This provided a better environment for the sporulation of oocysts, and the humidity made the wooden floor more sticky. By licking the lambs then easily became infected.

The habit of housed lambs to chew and lick on everything may be caused by nutritional deficiencies, and because of their 
frequently observed habit of eating soil such lambs may rapidly pick up a high rate of oocysts when transferred to pasture. The tube-feeding of lambs with $10-50 \mathrm{~g}$ of soil suspended in water is an artificial method, but the quantum lies within the limits of what is possible for a lamb to pick up during a couple of days. In Experiment no. 4 with $10-50 \mathrm{~g}$ of soil and in Experiment no. 6 with $50 \mathrm{~g}$ of soil from permanent pasture all the 10 treated lambs developed diarrhoea from 13-18 days after treatment, and 2 of them died. From 16 days onward after tube-feeding a spectacular rise in the oocyst counts occurred. In 10 untreated control lambs no diarrhoea was observed, and the oocyst counts remained on a moderate level for a longer period. Similar reactions were not observed in Experiment no. 5 with 25-50 g of infected soil, as only 1 of the 3 tube-fed lambs developed diarrhoea, and the oocyst counts were irregular, although a tendency to increase from 16 days onward after dosing was observed. It was, however, found that these 2 month-old lambs had been exposed to coccidial infection for several weeks prior to the experimentally induced infection. This might be expected to produce an immunity. With the exception of these lambs and the lambs of Experiment no. 2 which grazed the permanent pasture for 2 days only, the frequency of diarrhoea of all other groups which were exposed to what has been called a high level of infection, was significantly higher than that in lambs on a low level of infection. The lambs of Experiments nos. 4 and 6 which were artificially infected with soil from Pasture 4 reacted more seriously than lambs which grazed that pasture. This may be due to a heavier and more sudden infection in the dosed lambs.

The lack of clinical symptoms in lambs given clean soil as well as in untreated control lambs shows that the soil in itself had no deleterious influence on the lambs. The oocyst counts also seemed to be unaltered by the treatment with clean soil. On examination of the soil from Pasture no. 4 only few oocysts were found. The experiment does not clarify whether it is these oocysts alone or an interaction with other agents in the soil which were responsible for the severe diarrhoea in the lambs. Soil from sheep pastures may contain winter resistant bacteria which may produce disease in lambs. No evidence of such infection was found in the dead lambs. The fact that sporulated oocysts were demonstrated in the soil, and the typical symptoms of coccidiosis in lambs given this soil, provide strong evidence 
that the disease observed was a simple coccidiosis. This is supported by the histological examination of the small intestines of the lamb which died in Experiment no. 6.

Under natural conditions lambs may be infected with coccidia by eating grass that has been contaminated with soil carried on the legs of the ewes. The short period required for the lambs to become infected does not indicate that this is the most important source of infection. The direct eating of soil is a more probable cause.

Pout has shown that the number of oocysts in faeces may be an unreliable measure of the level of coccidial infection. In this paper the highly significant differences of the oocyst counts on new and permanent pastures from about the 15th to 30th day on pasture have been used as a basis for the conclusion that the initial infection of the 2 pastures was entirely different. The oocyst counts in most of the lambs in this experiment were very low until they were turned out on pasture. These lambs were apparently highly susceptible to coccidial infection. If such lambs are exposed to a sudden infection of coccidia, an increase of oocysts in the faeces must be expected after the end of the incubation period. In the light of the observations by Pout it is not justifiable to use the peak level of this increase of oocyst counts as a direct measure of the level of infection. In the present experiment there was little correlation between the peak level of oocyst counts and the severity of the symptoms in the infected groups. This is shown in the Experiments nos. 3 and 6. In the latter all of 7 lambs which were treated with infected soil developed diarrhoea, and 2 died. In the former 5 of 10 on permanent pasture developed diarrhoea and none died. The peak of mean OPG of these 2 groups was on the same level.

The oocyst counts of these lambs were, however, entirely different from those of housed lambs from 16 days onward after the infection was introduced, and these counts must be considered a reliable measure of the general level of the exposure to infection during the first days on pasture. The clinical symptoms of lambs on the different levels of exposure to infection support this. It is evident that the initial level of infection can be evaluated by the oocyst counts during the first 2 weeks following the end of the incubation period. Later the significance of difference was reduced and sometimes conflicting. The development of immunity in the groups exposed to a high level of 
infection and an increase of the infection in groups with a low level of exposure may reasonably explain the reduction of the groups' differences.

The tolerance of coccidia to low temperatures has been demonstrated (Landers 1953, Norton \& Joyner 1968). Francalanci (1968) found that sporulated oocysts from rabbits were viable after having been frozen for 2 years.

Although many details of the winter resistance of the different species of sheep oocysts still have to be clarified, these experiments demonstrate that winter resistant oocysts in the pasture are the main source of infection in Norwegian lambs brought out on pasture from hygienic indoor environments. These results are contradictory to the opinion of Pellérdy (1965) who reports that pastures become almost coccidia free during the winter.

In other countries with different management systems the coccidial infection of lambs may present another picture. In Sweden with winter conditions similar to Norway's, Nilsson (1967, 1968) found that the main source of infection was indoor pens or an outdoor yard where housed sheep had free entrance. Such an initial infection may induce immunity before the lambs are transferred to infected pastures, but the infection may also camouflage a superinfection on pasture. In every kind of sheep management it is essential to know the source of infection. The demonstration of winter resistant oocysts as the main source of coccidial infection in lambs opens possibilities for the prevention and control of coccidiosis. One method is to avoid pastures grazed by sheep the previous years. Another method to prevent coccidiosis is to treat the lambs at the end of the incubation period (Helle). This is possible if one knows the date when the lambs were brought out on pasture. This subject will be discussed in another paper.

\section{REFERENCES}

Christensen, J. F.: Experimental production of coccidiosis in silagefed feeder lambs with observations on oocysts discharge. $N$. Amer. Vet. 1941, 22, 606-610.

Francalanci, G.: Gli effetti delle basse temperature sulla sporulazione e sopravvivenza delle oocisti di Eimeria perforans, media, magna ed irresidua. (Effect of low temperature on sporulation and survival of the oocysts of Eimeria perforans, media, magna 
and irresidua). Nuova Vet. 1968, 44, 256-263. (Ref. in Vet. Bull. $1969,39$, ref. no. 1964$)$.

Helle, O.: Coccidiose hos sau. (Coccidiosis in sheep). Medlemsbl. norske Vet.-Foren. 1964, 16, 117-127.

Helle, O.: Epidemiologien ved coccidiose hos sau i Norge. (The epidemiology of coccidiosis of sheep in Norway). X. Nord. Vet.Congr., Proc. Stockholm 1967, 929-934.

Joyner, L. P., C. C. Norton, S. F. Davies \& C. V. Watkins: The species of coccidia occurring in cattle and sheep in the South-West of England. Parasitology 1966, 56, 531-541.

Kotlán, A., L. P. Pellérdy \& L. Versény: Experimentelle Studien über die Kokzidiose der Schafe. I. Die endogene Entwicklung von Eimeria parva. (A study of coccidiosis in sheep and of the tissue stages of development of Eimeria parva). Acta vet. Acad. Sci. hung. 1951, 1, 317-331.

Landers, E.: The effect of low temperatures upon the viability of unsporulated oocysts of ovine coccidiosis. J. Parasit. 1953, 39, $547-552$.

Lotze, John C.: Life history of the coccidian parasite Eimeria arloingi, in domestic sheep. Amer. J. vet. Res. 1953, 14, 86-95.

Nilsson, O.: Coccidios - en allvarlig lammsjukdom. (Coccidiosis a serious disease of lambs). Fårskötsel 1967, 47, 79-80.

Nilsson, O.: Coccidiepopulationen hos kliniskt normala får. (The population of coccidia in clinically normal sheep). Nord. Symp. Parasit. II. Proc. in Finska Vetenskaps-Societetens Parasitologiska Institut, Information 9, Åbo 1968, 29.

Norton, C. C. \& L. P. Joyner: The freeze preservation of coccidia. Res. vet. Sci. $1968,9,598-600$.

Pellérdy, L. P.: Coccidia and coccidiosis. Akad. Kiadó, Budapest 1965, p. 657.

Pout, D. D.: Coccidiosis in lambs. Vet. Rec. 1965, 77, 887.

Shumard, R. F.: Experimentally induced ovine coccidiosis. I. Use of nitrofurazone in the feed. Vet. Med. 1959, 54, 421-425.

Siegel, S.: Nonparametric Statistics for the Behaviorial Sciences. McGraw-Hill, New York, Toronto, London 1956, p. 312.

\section{SUMMARY}

Lambs born in pens with slatted floor were brought out at $2-5$ weeks of age on pastures heavily grazed by sheep the previous years. About 16 days later the oocyst output of the lambs rapidly increased to high levels. Lambs on pastures which never had been grazed by sheep earlier, had moderate oocyst counts.

Between 11 and 25 days after the beginning of grazing there were significantly more lambs with diarrhoea on permanent pastures compared with pastures never grazed by sheep earlier.

It was found that lambs were heavily infected during the first 2 days on permanent pastures. 
Thirteen housed lambs were given $10-50 \mathrm{~g}$ of soil from a permanent pasture as a water suspension by a stomach tube. Fifteen days later there was a steep rise in the oocyst output in most of them, and 11 of the 13 lambs developed diarrhoea and 2 died. None of 10 lambs given uninfected soil and none of 12 untreated controls showed diarrhoea and the oocyst output remained on a moderate level.

It is concluded that oocysts which have survived the winter in the pasture are the main source of infection with Eimeria spp. in lambs with this kind of management. Soil-eating is the most likely source of infection during the first days on pasture.

\section{SAMMENDRAG}

Overvintrede oocyster $i$ beiter som smittekilde for coccidiose hos lam.

Lam som var født inne i binger med spaltegulv ble sluppet ut 2-5 uker gamle på beiter som hadde vært brukt til sau de foregående år. Ca. 16 dager etter utslipping inntrådte en meget sterk stigning av oocystemengden i fæces. Lam på beiter som ikke hadde vært brukt til sau tidligere, hadde moderate oocystetall. Fra 11 til 25 dager etter utslipping var det signifikant flere lam som hadde diaré på beiter som hadde vært brukt til sau tidligere sammenlignet med lam på nye beiter.

Det viste seg at lamma kunne bli sterkt infisert i løpet av de to første beitedager.

Jord fra et beite som hadde vært brukt til sau de foregående år, ble gitt som vandig suspensjon med magesonde til 13 lam i mengder fra 10 til $50 \mathrm{~g}$. Femten dager senere opptrådte det store mengder oocyster i fæces hos de fleste av dem, og 11 av de 13 lamma fikk diaré og 2 døde. Ingen av 10 lam som fikk jord fra ubesmittet område og ingen av 12 ubehandlede kontroll-lam fikk diaré, og oocysteantallet i fæces holdt seg på et moderat nivå.

Det konkluderes med at oocyster som har overlevet vinteren $i$ beitet er den mest vanlige smittekilde for Eimeria spp. hos lam under vanlige norske driftsforhold. Det antas at lamma blir infisert ved á ete jord som inneholder oocyster.

(Received December 12, 1969). 
Acta vet. scand. $1970,11,565-570$.

From the Department of Anatomy and Embryology, College of Veterinary Medicine, Helsinki, Finland.

\title{
THE EFFECT \\ OF SOME FACTORS ON THE CELL VOLUME OF RUMEN CILIATES
}

\author{
By \\ Bengt W'esterling
}

The significance of the rumen ciliate fauna in the nitrogen conversion chain in the ruminant forestomachs is a question not conclusively solved. Efforts have been made to calculate the magnitude of the fauna, with the intention of estimating the amount of ciliate protein available daily to the host animal. Some of these calculations have been based on ciliate counting and geometrical computation of the ciliate cell volumes using the ellipsoidal form of the ciliates as basis for the computations (Mowry \& Becker 1930, Schumacher 1962, Harmeyer 1963).

The sources of error inherent in the counting methods applied, have been thoroughly tested (Boyne et al. 1957, Warner 1962, Harmeyer), while factors affecting the cell volumes have received less attention.

Factors most likely to cause errors in the volume computations seem to be 1) osmotic effects on the cells, caused by dilution of the rumen sample with hypotonic liquids, 2) the possible shrinking effect of formol or other fixatives and 3 ) the practice of conceiving ophryoscolecid ciliates in general as rotation ellipsoid bodies rather than as bilaterally compressed organisms.

The intention with the present investigation was to test the significance of possible errors inherent in the above mentioned phenomena and practices. 


\section{MATERIAL AND METHODS}

In testing the first 2 mentioned factors, rumen ciliates simultaneously obtained from the same host were subjected to 3 different treatments: 1) immediate volume determination, 2) determination after dilution of the rumen sample with water and 3 ) determination after formol fixation.

The rumen samples were obtained from 2 sheep in connection with rumen fistulation. Sheep no. 1 was starved overnight while sheep no. 2 was fed its usual morning ration, consisting of hay and grain, on the day of fistulation. From both sheep, 3 samples, consisting of about $200 \mathrm{ml}$ well mixed whole rumen contents each, were taken. The first one was collected in a prewarmed $\left(39^{\circ} \mathrm{C}\right)$ thermos-flask, the second one was diluted 1:1 with luke warm tap water and the third one was diluted 1:10 with $4 \%$ formol.

The volume determinations were based on the ellipsoid formula, $V=\frac{\mathrm{L}}{2} \times \frac{\mathrm{W}}{2} \times \frac{\mathrm{T}}{2} \times \frac{4}{3} \pi \mathrm{r}^{3}$, where $\mathrm{L}=$ the mean cell length of the species concerned (excluding possible spination), $\mathrm{W}=$ the mean width $=$ the dorso-ventral diameter measured at the widest part of the cell and $T=$ the mean thickness $=$ the transdiameter measured at the thickest part of the cell. In this part of the investigation however, no measurements of thickness were taken. The mean thicknesses were calculated from the width/thickness ratios of respective ciliate species given by Kofoid \& MacLennan (1932).

The ciliate species studied were Diplodinium (Eudiplodinium) maggii Fior. and Diplodinium (Diplodinium) dentatum Schuberg from sheep nos. 1 and 2 and Epidinium ecaudatum (Fior.) f. ecaudatum Crawley from sheep no. 2 alone. From the differently treated samples, measurements of length and width on 40 specimens of each species were taken and the respective mean dimensions and the errors of the means were computed.

The measuring of cells from the undiluted (native) samples was performed immediately after sampling. The ciliates, though, were too motile to be measured, why the slide preparations had to be chilled for some minutes in a refrigerator before taking the measurements. The taking of measurements from the samples diluted with water was started 2 hrs. after sampling and the formol fixed cells were measured 15 days after sampling.

The possible error arising when bilaterally compressed ciliates 
T a b l e 1. Length and width $(\mu \mathrm{m})$ of rumen ciliates in the native state, after water dilution of the samples and after formol fixation. The levels of significance of differences between the native and the treated states are shown.

\begin{tabular}{|c|c|c|c|c|c|c|}
\hline $\begin{array}{c}\text { Sheep } \\
\text { no. }\end{array}$ & Ciliate & $\begin{array}{l}\text { Native } \\
\text { dimens. }\end{array}$ & 2 hrs. $\mathrm{H}_{2} \mathrm{O}$ & $\begin{array}{c}\text { Level of } \\
\text { significance } \\
\quad \mathbf{P}<\end{array}$ & $\begin{array}{l}15 \text { days } \\
\text { formol }\end{array}$ & $\begin{array}{c}\text { Level of } \\
\text { significance } \\
\quad \mathrm{P}<\end{array}$ \\
\hline \multirow[t]{2}{*}{1} & D. dentatum & $\begin{array}{ll}\text { L } & 75.5 \pm 1.17 \\
\text { W } & 55.4 \pm 0.62\end{array}$ & $\begin{array}{l}82.0 \pm 1.44 \\
57.1 \pm 0.75\end{array}$ & $\begin{array}{c}0.001 \\
\text { no significance }\end{array}$ & $\begin{array}{l}77.4 \pm 1.41 \\
55.2 \pm 0.87\end{array}$ & $\begin{array}{c}\text { no significance } \\
,\end{array}$ \\
\hline & E. maggii & $\begin{array}{lr}\text { L } & 146.1 \pm 1.85 \\
\text { W } & 99.4 \pm 1.10\end{array}$ & $\begin{array}{l}153.7 \pm 2.42 \\
116.0 \pm 2.24\end{array}$ & $\begin{array}{l}0.01 \\
0.001\end{array}$ & $\begin{array}{r}147.2 \pm 2.47 \\
93.6 \pm 1.16\end{array}$ & 0.001 \\
\hline \multirow[t]{3}{*}{2} & D. dentatum & $\begin{array}{ll}\text { L } & 88.9 \pm 1.39 \\
\text { W } & 65.0 \pm 0.95\end{array}$ & $\begin{array}{l}97.7 \pm 1.64 \\
74.8 \pm 1.55\end{array}$ & $\begin{array}{l}0.001 \\
0.001\end{array}$ & $\begin{array}{l}81.3 \pm 1.20 \\
61.0 \pm 0.73\end{array}$ & $\begin{array}{l}0.001 \\
0.001\end{array}$ \\
\hline & E. maggii & $\begin{array}{lr}\text { L } & 146.9 \pm 1.96 \\
\text { W } & 95.4 \pm 1.24\end{array}$ & $\begin{array}{l}167.3 \pm 2.53 \\
125.8 \pm 2.00\end{array}$ & $\begin{array}{l}0.001 \\
0.001\end{array}$ & $\begin{array}{r}147.4 \pm 1.68 \\
92.7 \pm 0.88\end{array}$ & $\begin{array}{c}\text { no significance } \\
\text {, }\end{array}$ \\
\hline & E. ecaudatum & $\begin{array}{lr}\text { L } & 133.5 \pm 2.47 \\
\text { W } & 64.4 \pm 1.18\end{array}$ & $\begin{array}{r}139.0 \pm 2.60 \\
86.5 \pm 1.66\end{array}$ & $\begin{array}{c}\text { no significance } \\
0.001\end{array}$ & $\begin{array}{r}123.8 \pm 2.07 \\
62.8 \pm 1.48\end{array}$ & $\begin{array}{c}0.01 \\
\text { no significance }\end{array}$ \\
\hline
\end{tabular}

are regarded as rotation ellipsoids was calculated on the basis of measurements taken on ciliates from reindeer. The species measured were Entodinium anteronucleatum Dogiel, Diplodinium (Diplodinium) dogieli Dogiel, Diplodinium (Eudiplodinium) spectabile Dogiel and Enoploplastron triloricatum (Dogiel). The number of measurements taken on each dimension from the respective species was not the same for all species concerned, but was larger than 100 for length and width and more than $\mathbf{5 0}$ for thickness. On the basis of mean dimensions derived, 2 different volumes for each species were calculated - 1 according to the rotation ellipsoid formula, where the transdiameter of the cell is conceived being the same as the dorso-ventral diameter, and 1 using the calculated mean transdiameter.

The ciliates were measured in unstained wet preparations. The image of each cell was projected through a camera lucida on a measuring table and measured with a scale copy of a stage micrometer. The magnification amounted to some $440 \times$.

\section{RESULTS}

The effect on the cell dimensions obtained by dilution and formol fixation is shown in Table 1. The level of significance of the differences between the "native" state of the cells and the 
T a b l e 2. Calculated cell volumes $\left(\times 10^{-4} \mu \mathrm{m}^{3}\right)$ of rumen ciliates in the native state, after water dilution and after formol fixation. The percentage differences between the native and the treated states are shown.

\begin{tabular}{rlrrrrr}
\hline $\begin{array}{c}\text { Sheep } \\
\text { no. }\end{array}$ & Ciliate & Native & 2 hrs. $\mathrm{H}_{2} \mathrm{O}$ & $\begin{array}{c}\% \\
\text { increase }\end{array}$ & $\begin{array}{c}15 \text { days } \\
\text { formol }\end{array}$ & $\begin{array}{c}\% \\
\text { decrease }\end{array}$ \\
\hline \multirow{2}{*}{1} & D. dentatum & 9.7 & 11.2 & 15.4 & 9.7 & \multicolumn{1}{c}{0} \\
& E. maggii & 68.8 & 98.7 & 43.5 & 60.9 & 11.5 \\
2 & D. dentatum & 15.6 & 22.6 & 44.8 & 12.5 & 19.8 \\
& E. maggii & 63.7 & 126.2 & 107.3 & 60.5 & 5.0 \\
& E. ecaudatum & 29.0 & 54.6 & 88.3 & 25.6 & 11.7 \\
mean change in volume & & & +59.9 & & -9.6 \\
\hline
\end{tabular}

states caused by dilution and fixation respectively is also shown. In Table 2, the calculated mean cell volumes of each species, obtained after the treatments mentioned, are shown, as well as the percentage difference between the "native" and treated volumes.

The volumes calculated according to the 2 different ellipsoid formulas, and the percentage differences between the results are shown in Table 3.

T a b l e 3. Length, width and thickness (!lm) of some rumen ciliates and the cell volumes calculated according to $I)$ the ellipsoid formula and II) the rotation ellipsoid formula. The percentage difference between the results are shown.

\begin{tabular}{lcrccc}
\hline Ciliate & Dimens. & Mean $\pm \mathrm{E}_{\mathrm{M}}$ & $\begin{array}{c}\text { Volume I: ellipsoid } \\
\text { formula }\end{array}$ & $\begin{array}{c}\text { Volume II: rotation } \\
\text { ellipsoid formula }\end{array}$ & $\begin{array}{c}\text { Difference } \\
\text { in \% }\end{array}$ \\
\hline & $\mathrm{L}$ & $60.3 \pm 0.32$ & & & \\
E. anteronucleatum & $\mathrm{W}$ & $42.5 \pm 0.17$ & $3.7 \times 10^{4} \mu \mathrm{m}^{3}$ & $5.7 \times 10^{4} \mu \mathrm{m}^{3}$ & 54 \\
& $\mathrm{~T}$ & $27.6 \pm 0.29$ & & & \\
& $\mathrm{~L}$ & $103.9 \pm 0.38$ & & & \\
D. dogieli & $\mathrm{W}$ & $76.0 \pm 0.41$ & $17.8 \times 10^{4} \mu \mathrm{m}^{3}$ & $31.5 \times 10^{4} \mu \mathrm{m}^{3}$ & 77 \\
& $\mathrm{~T}$ & $43.1 \pm 0.55$ & & & \\
D. spectabile & $\mathrm{L}$ & $111.4 \pm 0.65$ & & & \\
& $\mathrm{~W}$ & $77.5 \pm 0.52$ & $21.0 \times 10^{4} \mu \mathrm{m}^{3}$ & $35.0 \times 10^{4} \mu \mathrm{m}^{3}$ & 67 \\
& $\mathrm{~T}$ & $46.5 \pm 0.83$ & & & \\
E. triloricatum & $\mathrm{L}$ & $89.9 \pm 0.63$ & & & \\
& $\mathrm{~W}$ & $47.1 \pm 0.29$ & $7.7 \times 10^{4} \mu \mathrm{m}^{3}$ & $10.4 \times 10^{4} \mu \mathrm{m}^{3}$ & 35 \\
& $\mathrm{~T}$ & $34.6 \pm 0.45$ & & & \\
\hline
\end{tabular}




\section{DISCUSSION}

The practice of diluting the rumen samples with water $1: 1$ was used by Mowry \& Becker (1930). Also Ferber (1928) determined the proportion of ciliates in the rumen contents in a way which involved a considerable dilution of the samples with water. The present investigation indicates that the ciliates absorb water from hypotonic solutions which causes them to swell. Consequently, determinations of volume or weight of the fauna which involve dilution of the rumen liquid with water, are apt to result in values considerably higher than the actual ones. The methodical error involved seems to be a significant one, and the fauna volumes presented by the above mentioned authors must be regarded too large.

The formol fixation seems to affect the cell dimensions less than the dilution with water. The mean effect on the calculated cell volumes was less than $10 \%$. It appears that the shrinkage as well as the above discussed swelling might to some extent depend on the feeding time of the host animal. Morphological details, such as the skeletal plates of the ciliates, might also influence the changes occurring in different dimensions of the cells. Because of the lack of uniformity in the changes observed, it seems unwise to draw conclusions about the magnitude of the errors caused by the treatments studied. Further investigations, including the testing of buffering methods, are required.

When the thickness of the cells was neglected, none of the computations performed revealed an error less than $35 \%$ of the actual cell volume. The large discrepancy between the cell volumes obtained by the 2 different geometrical approaches, indicates that the calculations of cell volumes ought to be based on the actual thickness of the species studied, as well as on the length and width.

\section{REFERENCES}

Boyne, A. W., J. M. Eadie \& K. Raitt: The development and testing of a method of counting rumen ciliate protozoa. J. gen. Microbiol. 1957, 17, 414-423.

Ferber, K. E.: Die Zahl und Masse der Infusorien im Pansen und ihre Bedeutung für den Eiweissaufbau beim Wiederkäuer. (The number and mass of infusoria in the rumen and their significance for the synthesis of protein in the ruminant). $Z$. Tierzücht. Züchtungsbiol. 1928, 12, 31-63. 
Harmeyer, J.: Isolierung, Differenzierung und analytische Ergebnisse der Protozoenfauna der Ziege. (Isolation, differentation and analytic results concerning the ciliate fauna of the goat). Thesis, Hannover 1963.

Kofoid, C. A. \& R. F. MacLennan: Ciliates from Bos indicus Linn., II. A revision of Diplodinium Schuberg. Univ. Calif. Publ. Zool. 1932, 37, 53-152.

Mowry, H. A. \& E. R. Becker: Experiments on the biology of infusoria inhabiting the rumen of goats. Iowa St. Coll. J. Sci. 1930, 5, $35-60$.

Schumacher, E.: Über die Wirkung einiger Sulfonamide und Antibiotika auf die Infusorien und die Gärgasbildung im Panseninhalt des Rindes. (About the effect of some sulfonamides and antibiotics on the ciliates and the formation of gas in the rumen contents of cattle). Habilitationsschrift Univ. Zürich. Schweiz. Arch. Tierheilk. 1962, 104, 491-518.

Warner, A. C. I.: Enumeration of rumen micro-organisms. J. gen. Microbiol. 1962, 28, 119-128.

\section{SUMMARY}

The effect of diluting rumen samples with water and that of formol fixation, on the volume of ophryoscolecid rumen ciliates, was studied. The dilution with water caused within $2 \mathrm{hrs}$. the ciliates to swell to an average of $60 \%(15.4-107.3)$. During 15 days of formol fixation, the shrinkage was on an average $10 \%(0.0-19.8)$ of the original volume.

When the thickness of the cells was conceived equal to the width, volumes $35-77 \%$ too large were obtained.

The influence of these sources of error on calculations of rumen fauna volumes is discussed.

\section{SAMMANFATTNING}

Några faktorers effekt på våminfusoriers cellvolym.

I undersökningen studerades effekten av vattenspädning och formolfixering på volymen hos våmciliater av familjen Ophryoscolecidae. Spädning av våmproven med vatten fick cellerna att inom 2 timmar svälla med i medeltal $60 \%(15,4-107,3)$. Formolfixering av proven i 15 dagar förorsakade en krympning på i medeltal $10 \% \quad(0,0-19,8)$ av den ursprungliga volymen.

När cellernas tjocklek sattes lika med bredden, erhölls 35-77\% för stora cellvolymer.

Dessa felkällors betydelse för beräkning av våmfaunans storlek diskuteras. 